\title{
DRYING CHARACTERISTICS OF OKRA PODS DURING DRYING PROCESS IN A HOME MICROWAVE OVEN
}

\author{
Abd El-Wahab S. Kassem ${ }^{1}$, Abdulwahed M. Aboukarima ${ }^{2}$ and \\ Hamza A. Morghany ${ }^{3}$
}

ABSTRACT

Okra is an important vegetable for different people all over the world. Because of its high moisture content, okra is susceptible to rapid deterioration. The aim of the present work was to determine the effect of a home microwave output powers on drying of okra pods. Okra was dried from initial moisture content of about $89.12 \%(w . b)$ to a safe level of about $9.62 \%(w . b)$ under different microwave output power levels (75, 150, 300, 500, 700 and $900 \mathrm{~W}$ ) using the process 1 min ON and switch OFF the microwave oven for $5 \mathrm{~min}$. The obtained data show that, there by increasing the used microwave output powers for drying sample of $100 \mathrm{~g}$, the drying time leading to decrease from 19 to $13 \mathrm{~min}$. To determine the kinetic drying model parameters, the drying data were fitted to four drying models based on the ratio of the final and initial moisture contents versus drying time. Among of the models proposed, the Midilli-Kucuk model gave a better fit for all drying conditions applied. It is expected that this study would be very beneficial to those dealing with the microwave drying systems of the future.

\section{INTRODUCTION}

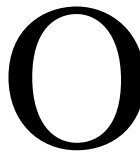
$\mathrm{kra}$ is an important vegetable for different people all over the world due to its low in saturated fat and cholesterol and is very good source of dietary fiber, vitamin $\mathrm{C}$, vitamin $\mathrm{A}$, calcium and magnesium (Dadali et al., 2007). Fresh harvested okra has very high moisture content

1.Proffesor, Agricultural Engineering Department, Faculty of Agricultural, Alexandria University, Egypt.

2.Researcher, Engineering Research Institute, Agricultural Research Center, Egypt. Currently is Assistant Professor at Community College, Huraimla, Shaqra University, P.O. Box 300, Huraimla 11962, Saudi Arabia.

3.Researcher, Engineering Research Institute, Agricultural Research Center, Egypt. 
(88-90\% w. b) with safe moisture content for storage of $10 \%$ wet basis (Shivhare et al., 2000). Due to high moisture content, it is strongly subjected to rapid deterioration, resulting in chemical, physical and biological changes. Under these conditions its shelf life does not exceed (Kumar and Prasad, 2010). Because of its sensitivity to storage, most fresh okras are preserved in some form. Freezing may prolong the life of this vegetable. Okra can be dried for later use (Adom et al., 1997).

Drying is the oldest and most widely used primary method of food preservation. In general, it is a means of removal of water from the material. The purpose of drying food products is to allow longer periods of storage with minimized packaging requirements, reduce shipping weights, and preserve seasonal plants and make them available to consumers during the whole year. Also, some changes take place, as structural and physicochemical modifications, which affect the final product quality during drying process (Apar et al., 2009).Traditionally, slices or pods okra are preserved using sun drying on the ground, racks, trays and is stored in the kitchen. Another most common method used for drying of okra is hot air drying. In both the methods drying time is long (days) and quality also deteriorates due to long exposure to heat. To overcome these, faster and effective techniques like microwave drying, freeze drying are becoming popular (Kumar and Prasad, (2010). However, over the past two decades, there has been an increasing interest in microwave drying to reduce drying time and increase the removal of water from fruits (Sanga et al., 2000).

Microwave heating is dielectric heating. While microwave is processing, microwaves radiate from a source in all directions. These waves carry energy; and during drying process, material absorbs this energy and converts it to heat by polar molecules. Water is the common polar molecule and a component of foods. So, during this process, water molecules convert microwave energy to heat. Then, the water molecules start to evaporate as a result of this heat, and so on material starts to dry (Decareau, 1985). Inchuen et al. (2008) reported that microwave drying process are consisted of three drying periods, i.e. heating up, constant rate and falling rate periods.

Microwave drying is rapid, more uniform and energy efficient, compared 
to conventional hot air drying (Haghi and Amanifard, 2008; Tontand and Therdthai, 2009). The advantages of fast heating in microwave ovens are well established. The number of microwave drying applications clearly shows the advantages of this heating technique. The application of microwave in the drying process is well-known in term of faster drying time due to volumetric heating of dielectric materials (Changrue, 2006). In a study of Adom et al. (1997) slice thickness and drying time of okra (Hibiscus esculentus) during solar drying showed affect on color, viscosity, microbial load, moisture, crude fiber, vitamin $\mathrm{C}$ and ash contents. They used three slice thicknesses $(5.0 \mathrm{~mm}, 10.0 \mathrm{~mm}$ and 15.0 $\mathrm{mm})$ and five drying times (0, 24, 48, 72 and $96 \mathrm{~h})$. The study showed that a slice thickness of $10.0 \mathrm{~mm}$ and a drying time of $48 \mathrm{~h}$ were suitable for the solar drying of okra.

Shivhare et al. (2000) studied effects of size (whole and sliced), pretreatment (blanching in water and $0.5 \% \mathrm{NaCl}$ solution at $95^{\circ} \mathrm{C}$ ) and temperature of drying air $\left(40,55\right.$ and $\left.70^{\circ} \mathrm{C}\right)$ on the drying characteristics and quality of okra. Their main finding was that the drying rate of okra takes place under the falling rate period. Page's model was found to adequately describe the drying behavior of okra. The quality of the dried product was found to be best when the okra was sliced and blanched at $95^{\circ}$ $\mathrm{C}$ in $0.5 \% \mathrm{NaCl}$ solution for $5 \mathrm{~min}$ and then dried at $55^{\circ} \mathrm{C}$.

Doymaz (2005) investigated air-drying characteristics of okra in a laboratory scale hot-air dryer for a temperature range $50-70{ }^{\circ} \mathrm{C}$, and a relative humidity range $8-25 \%$. Results indicated that drying took place in the falling rate period. The Page model gave the best fit for describing single layer drying of okra.

Dadali et al. (2007) investigated the effects of power level and sample mass on moisture content, moisture ratio, drying rate, and drying time of Turkey okra (Hibiscus esculenta L.) using microwave drying technique. Various microwave power levels ranging from 180 to $900 \mathrm{~W}$ were used for drying of $100 \mathrm{~g}$ of okra. The samples in the range of 25 to $100 \mathrm{~g}$ were dried at microwave power level of $360 \mathrm{~W}$. Page's model gave a better fit for all drying conditions used.

Ozbek and Dadali (2007) investigated the effect of microwave drying technique using domestic digital microwave oven on moisture content, 
moisture ratio, drying rate, drying time and effective moisture diffusivity of mint leaves (Mentha spicata L.). Results showed that by increasing the microwave output powers (180-900 W) and the sample amounts (25-100 $\mathrm{g}$ ), the drying time decreased from 12.50 to $3.0 \mathrm{~min}$ and increased from 6.60 to $16 \mathrm{~min}$, respectively. Also, among of the drying models proposed, the semi-empirical Midilli et al. model gave a better fit for all drying conditions applied.

Kassem et al. (2011) investigated the effect of combined microwave oven and hot air cabinet dryer on drying characteristics of Thompson seedless grapes. Results showed that within a certain microwave power range (75$900 \mathrm{~W}$ ), increasing microwave power speeds up the drying process, thus shortening the drying time.

Mohamed et al. (2010) found that the best fitting model for describing the drying curves of okra dried in the forced convective indirect solar dryer with air flow rate of $0.075 \mathrm{~m}^{3} / \mathrm{s}$ was Midilli-Kucuk model.

Kumar and Prasad (2010) conducted a study to investigate the potential of microwaves combined with hot air for drying of okra. Okra was dried from initial moisture content of about $89 \%$ w.b to a safe level of about 0.1 $\mathrm{g}$ water/ $\mathrm{g}$ dry matter under different combinations of air velocity ( 1 and 2 $\mathrm{m} / \mathrm{s})$, hot air temperature $\left(40,50,60\right.$ and $\left.70^{\circ} \mathrm{C}\right)$ and microwave power levels $(0.5,1,1.5,2$ and $2.5 \mathrm{~W} / \mathrm{g})$. Drying time in microwave-convective drying decreased by many folds as compared with hot-air drying. Drying time was found decreasing with increase in either air temperature or microwave power level. However, effect of air temperature was more significant at lower microwave power levels. Most of the drying took place in falling rate period. Empirical Page model gave the excellent fit for the drying data under all drying conditions with coefficient of determination values in the range of 0.988-0.999.

Demirhan and Özbek (2010) investigated the effect of microwave-drying technique on moisture content, moisture ratio, drying rate, drying time and effective moisture diffusivity of basil leaves (Ocimum Basillium L.). By increasing the microwave output powers (180-900 W) and the sample amounts $(25-100 \mathrm{~g})$, the drying time decreased from 28 to $6.5 \mathrm{~min}$ and increased from 16 to $44 \mathrm{~min}$, respectively. The semi-empirical logarithmic model gave a better fit for all drying conditions applied. 
Although solar cabinet drying with cabinet dimensions $1.93 \times 0.6 \mathrm{~m}$ is a popular and very inexpensive method, but dependable solar dehydration of $3.0 \mathrm{~kg}$ of okra requires 2 days when the temperature is $66{ }^{\circ} \mathrm{C}$ (Grabwski and Marcotte, (2003). On the other hand, drying vegetables and fruits in the microwave oven has different advantages as mentioned above. Based on these advantages, a study was undertaken to observe drying characteristics of okra pods during drying process in available microwave oven at home. However, there are different cycles to operate the microwave oven in drying purposes. So, the aim of this work was to study the drying kinetics of okra cultivated in Egypt undergoing microwave oven at various power levels under operation cycle of 1 minute ON then 5 minutes OFF. The information obtained could be an encouraged effort to use the available microwave oven at home for drying process. Also, it can be used to estimate the moisture content of okra pods at any time during the microwave drying.

\section{MATERIALS AND METHODS}

\section{Sample preparation}

Green fresh okra pods with similar size, shape and color were obtained from a farm near to Alexandria Governorate, Egypt during the summer season of 2010. Approximately $5 \mathrm{~kg}$ of the okra was brought for the experiment. From the samples, 100 pods were selected at random for determining their lengths using a vernier calliper reading to $0.01 \mathrm{~mm}$. The pods were sized $(3-4 \mathrm{~cm})$. The okra pods were stored in refrigerator at 4$5^{\circ} \mathrm{C}$ for about one day in order to moisture equilibrates moisture and then used for drying experiments. The quantity of okra pods to be used in a day is removed from the refrigerator and kept under ambient room conditions for a period before drying experiments to attain room temperature and were washed in clean water. The okra samples were blanched in the hot water at temperature $95^{\circ} \mathrm{C}$ for $5 \mathrm{~min}$. and were immediately cooled in the chilled water to avoid over processing (Kumar and Prasad, 2010). The top and tip were separated and remainder okra pod was used without cut.

The electric laboratory oven (Model $\mathrm{mLw}$ ) was used to determine the initial moisture content of the okra samples. A known weight of sample 
was dried in the electric oven which adjusted at $70^{\circ} \mathrm{C}$ for $24 \mathrm{~h}(\mathrm{AOAC}$, (1984). Reported values of the initial moisture content are means of 3 replications. The mean initial moisture content of the okra samples was $89.12 \pm 0.4 \%$ (w. b).

\section{Drying equipment and drying procedure}

Drying treatment was performed in a home microwave oven (Moulinex Model PTiMO, Fig.(1) with technical features of $220 \mathrm{~V}$ and $50 \mathrm{~Hz}$. The microwave oven has the capability of operating at different microwave output powers, being $75,150,300,400,500,600,700,800$ and $900 \mathrm{~W}$. The area on which microwave drying is carried out was $335 \times 330 \times 210 \mathrm{~mm}$ in size.

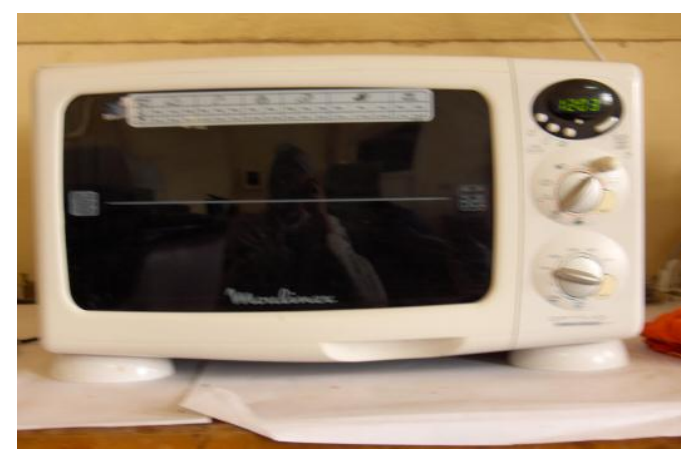

Fig.(1) Photograph of the microwave oven used in drying okra.

The adjustment of microwave output power and processing time was done with the aid of knobs located on the microwave oven. During drying experiments sample of $100 \mathrm{~g}$ was uniformly spread in a square glass dish with diameter of $31 \mathrm{~cm}$ and about $1 \mathrm{~cm}$ depth in a single layer and placed at the centre of the oven. Some microwave output power levels $(75,150$, 500,700 or $900 \mathrm{~W}$ ) were investigated in this study.

The drying procedure was done by operating the microwave oven for operation cycle of 1 minute ON then 5 minutes OFF for specific microwave power. Moisture loss was periodically measured by taking out the glass dish and weighing on the digital balance with a precision of 0.01 g. Three replications of each experiment were performed according to a preset microwave output power. The data given was an average of these results. The microwave power was applied until the desired final weight of dry okra pods was obtained. However, this desired final weight of dry okra pods was calculated as follows (Brennand, 1994): 
PROCESS ENGINEERING

$$
\text { Desired dry Wt. }(g)=\frac{(\text { Raw Wt.g }) \times(\text { Solids } \%)}{90 \%}
$$

In this research, the solids in the raw okra pods is about $11 \%$, so, according to Eq. (1), the desired dry weight of okra pods during drying experiments will be about $12 \mathrm{~g}$. of $100 \mathrm{~g}$ raw weight.

All weighing processes during drying experiments were completed in less than 10 s. Fig. (2) shows the flow chart of the procedures during drying experiments. The experiments were executed at Agricultural Engineering Department, Faculty of Agriculture, Alexandria University, El Chatby, Alexandria, Egypt.

\section{Drying models}

Drying kinetics is the description of the changes of moisture content of material during drying.The dimensionless moisture ratio (MR) expression is used in the drying models (Xanthopoulos et al., 2007).The MR is expressed as:

$$
\begin{aligned}
& M R=\frac{M-M e}{M i-M e} \\
& M R=\frac{M}{M i}
\end{aligned}
$$

Where $\mathrm{M}$ is the moisture content (\% db at drying time $\mathrm{t})$, $\mathrm{Mi}$ is the initial moisture content $(\% \mathrm{db}), \mathrm{t}$ is the drying time (min), and $\mathrm{Me}$ is the equilibrium moisture content $(\% \mathrm{db})$. The equilibrium moisture content (Me) was assumed to be zero for microwave drying (Dadali et al., 2007; Maskan, 2000; Soysal, 2004).Thus, Eq. (2) can be reduced to:

The dimensionless moisture ratio (MR) presented by Eq. (3) will be used in drying models. The data obtained from the drying experiments were analyzed using statistical software package. 
PROCESS ENGINEERING

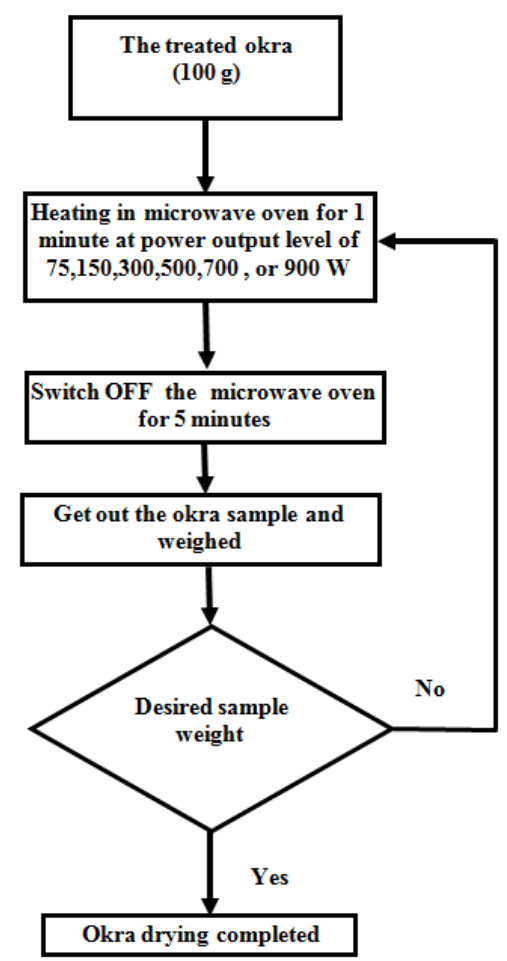

Fig. (2) Flow chart of the procedures during drying experiments in a home microwave oven.

In microwave drying, different researchers reported that there are different drying models could describe characteristics of drying process of vegetables and fruits. In this study, four thin-layer (thickness of okra pod) drying models were fitted to the observed data, and comparison was carried out using goodness-of fit statistical parameters. The first model is Page's model (Eq. 4). It is used in describing drying characteristic of air drying of okra (Domayz, 2005), microwave drying of okra (Dadali et al., 2007) and solar drying of okra (Mohamed et al., 2010).The Page's model is as follows (Page, 1949):

$$
M R=\exp \left(-k t^{n}\right)
$$

The second model is Midilli-Kucuk (Eq. 5) (Midilli et al., 2002). It is validity in describing drying characteristic of solar drying of okra (Mohamed et al., 2010).The equation is: 


$$
M R=a \exp \left(-k t^{n}\right)+b t
$$

The third model is Henderson and Pabis (1961) which describing in (Eq.6). It is used in describing drying characteristic of solar drying of okra (Mohamed et al., 2010).The equation is:

$$
M R=a \exp \left(-k t^{n}\right)
$$

The fourth model is Lewis (Eq. 7) (Abalone et al., 2006). It is tried in describing drying characteristic of solar drying of okra (Mohamed et al., 2010).The equation is:

$$
M R=\exp (-k t)
$$

Where, $\mathrm{k}\left(\mathrm{min}^{-1}\right), \mathrm{n}$, a and $\mathrm{b}$ (dimensionless) are the drying constants and $\mathrm{t}$ is drying time (min).

The non regression analysis was performed using the statistical computer program (SPSS, 2005). The goodness of fit of the tested mathematical models to the experimental data was evaluated using three statistical parameters namely; coefficient of determination $\left(\mathrm{R}^{2}\right)$, reduced chi-square $\left(\chi^{2}\right)$ between the predicted and experimental values and root mean square error (RMSE). The reduced chi-square $\left(\chi^{2}\right)$ and root mean square error (RMSE) are calculated as follows:

$$
\begin{aligned}
& \chi^{2}=\frac{\sum_{i=1}^{i=N}\left(M R_{i o b s}-M R_{i_{p r e}}\right)^{2}}{N-n_{p}} \quad(\text { McMinn, 2006) } \\
& R M S E=\sqrt{\frac{\sum_{i=1}^{i=N}\left(M R_{i_{o b s}}-M R_{i p r e}\right)^{2}}{N}} \quad(\text { McMinn, 2006) }
\end{aligned}
$$


Where $\mathrm{MR}_{\text {iobs }}$ is observed moisture ratio, $\mathrm{MR}_{\text {ipre }}$ is estimated moisture ratio by different models, $\mathrm{N}$ is number of time intervals, and $\mathrm{n}_{\mathrm{p}}$ is number of constants in the model. The higher the $\mathrm{R}^{2}$ values and the lower the $\left(\chi^{2}\right)$ and RMSE values, the better is the goodness of fit.

\section{$\underline{\text { Statistical analysis }}$}

The experimental data were statistically analyzed, using one-way analysis of variance (ANOVA) for the randomized complete design with

three replicates. The used software was SAS (1986) using ANOVA procedure. Comparisons among treatment means, when significant, were conducted using least significant difference (LSD) at $\mathrm{p}=0.05$ level.

\section{RESULTS AND DISCUSSION}

Effect of microwave output power on moisture content, moisture ratio, drying rate and drying time of okra pods

To investigate the effect of microwave output power on moisture content, moisture ratio, drying rate and drying time, six microwave output powers; $75,150,300,500,700$ and $900 \mathrm{~W}$ were used for drying of $100 \mathrm{~g}$ okra pods. As the microwave output power was increased, the drying time of samples was significantly decreased, as expected. The microwave drying process which reduced the moisture content of okra pods from 819.12 to about $10.65 \%$ db took 19-13 min, depending on microwave output power applied. By working at $900 \mathrm{~W}$ instead of $75 \mathrm{~W}$, the drying time was shortened by $32 \%$.The drying times obtained in this present study was extremely low (as compared with the results obtained from the previous studies. Mohamed et al. (2010) in their work concluded that during solar drying of Egyptian okra, weight of approximately $5000 \mathrm{~g}$ and drying time of $16 \mathrm{~h}$ would be most suitable for the solar drying of okra. The obtained results in this present work as compared with the solar drying by Mohamed et al. (2010), the drying time can be shortened by 1.5 -fold by working at microwave output power of 900 W.The drying rate was calculated as the quantity of moisture removed per unit time per unit dry 
matter (g water/g dry matter/min). The moisture content of the pods was very high during the initial phase of the drying which resulted in a higher absorption of microwave power and higher drying rates due to the higher moisture diffusion as reported by (Soysal, 2005). Since, the initial moisture contents of okra pods used in drying experiments were relatively constant (8.19 g water/g dry mater), the difference in drying time requirements was considered to be mainly due to the difference in the drying rates as reported by (Ozbek and Dadali, 2007) which were given in Fig. (3).As can be seen from this figure, depending on the drying conditions, short constant rate period was observed and exhibited approximately linear. Also, it can be seen that higher drying rates were obtained at higher microwave power. Thus, the power had a vital effect on the drying rate of okra pods. Similar findings were reported in several previous studies (Sosyal, 2005; Inchuen et al., 2008; Kassem et al., 2010; Shah and Joshi, 2010).

\section{Mathematical modeling}

Mathematical modeling of the drying curves (Fig.4) under various microwave power levels was conducted using nonlinear regression analysis. All the model constants were calculated based on the iterative method and the statistical parameters for the estimation are listed in Table (1).

Based on the obtained results values for the three statistical parameters, it can be seen that the semi-empirical Midilli-Kucuk equation was observed the most appropriate one to describe the drying kinetics of okra pods at all tested microwave powers with higher value for the coefficient of determination $\left(\mathrm{R}^{2}\right)$ and lower reduced chi-square $\left(\chi^{2}\right)$ and RMSE compared with the statistical values obtained for other models. The $\mathrm{R}^{2}, \chi^{2}$ and RMSE values ranging from 0.998-0.999, 0.00009-0.00023 and 0.00848-0.01310, respectively. The drying rate constant $(\mathrm{k})$ of MidilliKucuk model was found in the range of 0.0813 to $0.122 \mathrm{~min}^{-1}$, the constant ' $n$ ' was in the range of 1.262 to 1.338 , the constant ' $a$ ' was in the range of 0.997 to 1.008 and the constant ' $b$ ' was in the range of 0.005 to 0.006 . 


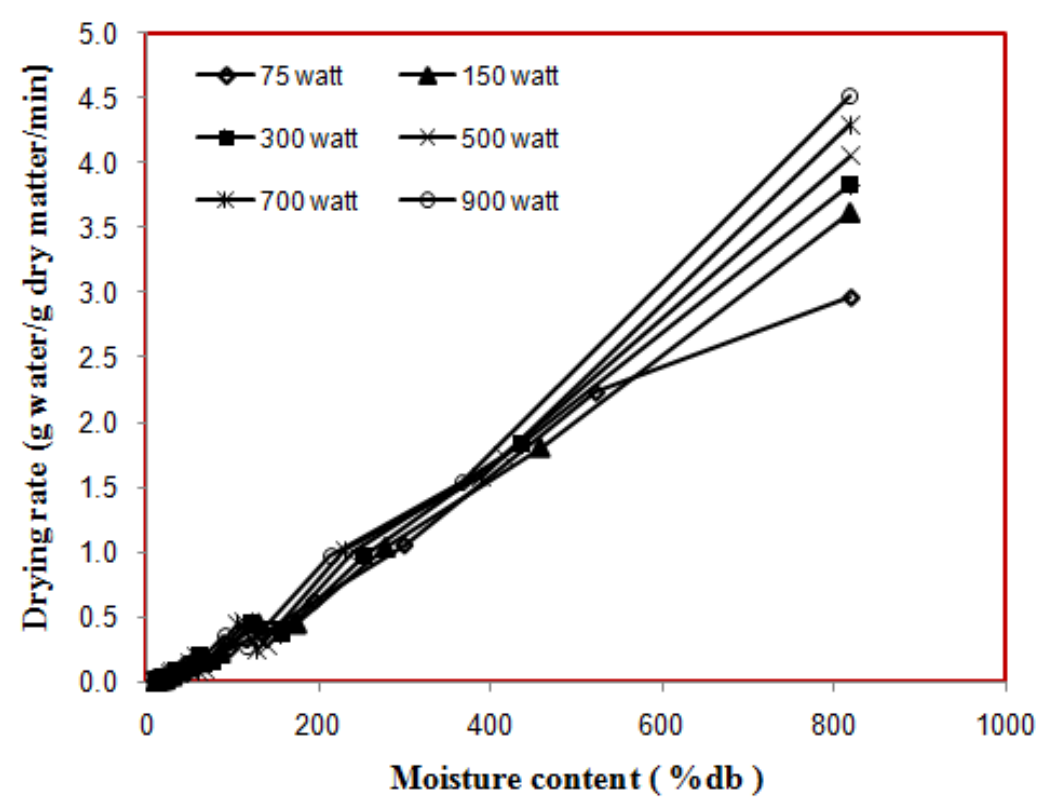

Fig.(3): Mean drying rate curves versus moisture content at various microwave output powers for sample of $100 \mathrm{~g}$. weight.

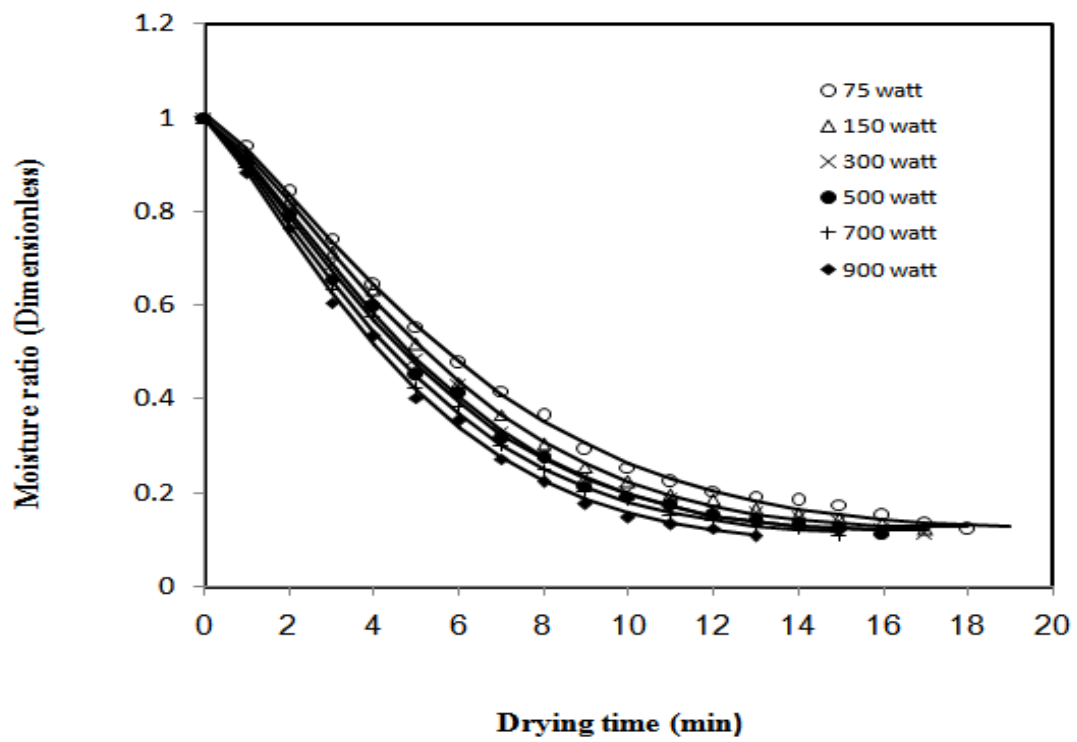

Fig.(4). Mean moisture ratios versus time at various microwave output powers. 
Table (1): Mean drying constant parameters and statistics criteria for moisture ratio estimation by different drying models and coefficients of determination when okra dried by microwave oven at different power levels with operation of cycle 1 minute $\mathrm{ON}$ and 5 minutes OFF.

\begin{tabular}{|c|c|c|c|c|c|c|c|}
\hline \multirow{2}{*}{ Model } & \multirow{2}{*}{ Parameters } & \multicolumn{6}{|c|}{ Microwave output power, W } \\
\hline & & 75 & 150 & 300 & 500 & 700 & 900 \\
\hline \multicolumn{8}{|c|}{ Lewis } \\
\hline & $\mathrm{k}$ & 0.125 & 0.135 & 0.144 & 0.151 & 0.160 & 0.175 \\
\hline & RMSE & 0.02957 & 0.03124 & 0.03086 & 0.02843 & 0.02743 & 0.02684 \\
\hline & $\chi^{2}$ & 0.00092 & 0.00103 & 0.00101 & 0.00086 & 0.00080 & 0.00078 \\
\hline & $\mathrm{R}^{2}$ & 0.989 & 0.988 & 0.988 & 0.990 & 0.991 & 0.991 \\
\hline \multicolumn{8}{|c|}{ Henderson \&Pabis } \\
\hline & $\mathrm{a}$ & 1.048 & 1.047 & 1.043 & 1.039 & 1.038 & 1.041 \\
\hline & $\mathrm{k}$ & 0.129 & 0.142 & 0.150 & 0.158 & 0.167 & 0.183 \\
\hline & RMSE & 0.02371 & 0.02684 & 0.02708 & 0.02490 & 0.02393 & 0.02225 \\
\hline & $\chi^{2}$ & 0.00066 & 0.00086 & 0.00088 & 0.00075 & 0.00071 & 0.00063 \\
\hline & $\mathrm{R}^{2}$ & 0.993 & 0.991 & 0.991 & 0.992 & 0.993 & 0.994 \\
\hline \multicolumn{8}{|c|}{ Page's model } \\
\hline & $\mathrm{k}$ & 0.099 & 0.109 & 0.118 & 0.125 & 0.132 & 0.136 \\
\hline & $\mathrm{n}$ & 1.098 & 1.102 & 1.098 & 1.096 & 1.101 & 1.139 \\
\hline & RMSE & 0.02450 & 0.02688 & 0.02682 & 0.02416 & 0.02252 & 0.01642 \\
\hline & $\square^{2}$ & 0.00067 & 0.00081 & 0.00081 & 0.00066 & 0.00058 & 0.00031 \\
\hline & $\mathrm{R}^{2}$ & 0.992 & 0.991 & 0.991 & 0.993 & 0.994 & 0.997 \\
\hline \multicolumn{8}{|c|}{ Midilli-Kucuk } \\
\hline & $\mathrm{a}$ & 1.008 & 0.999 & 0.997 & 0.998 & 0.998 & 0.998 \\
\hline & $\mathrm{b}$ & 0.0053 & 0.006 & 0.006 & 0.006 & 0.006 & 0.005 \\
\hline & $\mathrm{k}$ & 0.0813 & 0.0830 & 0.0917 & 0.1013 & 0.1113 & 0.1220 \\
\hline & $\mathrm{n}$ & 1.285 & 1.338 & 1.334 & 1.294 & 1.278 & 1.262 \\
\hline & RMSE & 0.01068 & 0.00848 & 0.01068 & 0.01213 & 0.01310 & 0.01110 \\
\hline & $\chi^{2}$ & 0.00014 & 0.00009 & 0.00015 & 0.00019 & 0.00023 & 0.00017 \\
\hline & $\mathrm{R}^{2}$ & 0.999 & 0.999 & 0.999 & 0.998 & 0.998 & 0.999 \\
\hline
\end{tabular}

In agreement with other literatures, Midilli-Kucuk model often gave better prediction on the moisture distribution profile among other semitheoretical models (Ong and law, 2009). 
It is determined that the value of the drying coefficient $(\mathrm{k})$ increased with the increase in microwave output power. This implies that with the increase in microwave output power drying curve becomes steeper indicating faster drying of the product (Soysal, 2005).

\section{Statistical analysis}

Table (2) illustrates LSD test for means of final drying time, final moisture content and Midilli-Kucuk drying model parameters as affected by microwave powers during microwave drying process with different power levels. The results as seen in Table (2) shows a significant influence $(\mathrm{P}<0.05)$ of all power levels. It is obvious that the $75 \mathrm{~W}$ power level gave higher drying time, final moisture content compared with other power levels, Table (2).

Table (2): LSD test for means ${ }^{*}$ of final drying time, final moisture content and Midilli-Kucuk drying model parameters as affected by microwave powers during microwave drying process with different power levels.

\begin{tabular}{|c|c|c|c|c|c|c|}
\hline Treatment & $\begin{array}{c}\text { Drying } \\
\text { time }\end{array}$ & $\begin{array}{c}\text { Final } \\
\text { moisture } \\
\text { content }\end{array}$ & \multicolumn{4}{|c|}{$\begin{array}{c}\text { Midilli-Kucuk drying model } \\
\text { parameters }\end{array}$} \\
\cline { 2 - 7 } & $(\mathrm{min})$ & $\%, \mathrm{db})$ & $\mathrm{a}$ & $\mathrm{b}$ & $\mathrm{K}$ & $\mathrm{n}$ \\
\hline $75 \mathrm{~W}$ & $19 \mathrm{a}$ & $11.37 \mathrm{a}$ & $1.008 \mathrm{a}$ & $0.0053 \mathrm{~b}$ & $0.0813 \mathrm{e}$ & $1.285 \mathrm{c}$ \\
\hline $150 \mathrm{~W}$ & $18 \mathrm{ab}$ & $10.89 \mathrm{~b}$ & $0.999 \mathrm{~b}$ & $0.006 \mathrm{a}$ & $0.0830 \mathrm{e}$ & $1.338 \mathrm{a}$ \\
\hline $300 \mathrm{~W}$ & $17 \mathrm{bc}$ & $10.83 \mathrm{~b}$ & $0.997 \mathrm{~b}$ & $0.006 \mathrm{a}$ & $0.0917 \mathrm{~d}$ & $1.334 \mathrm{a}$ \\
\hline $500 \mathrm{~W}$ & $16 \mathrm{dc}$ & $11.33 \mathrm{a}$ & $0.998 \mathrm{~b}$ & $0.006 \mathrm{a}$ & $0.1013 \mathrm{c}$ & $1.294 \mathrm{~b}$ \\
\hline $700 \mathrm{~W}$ & $15 \mathrm{~d}$ & $10.85 \mathrm{~b}$ & $0.998 \mathrm{~b}$ & $0.006 \mathrm{a}$ & $0.1113 \mathrm{~b}$ & $1.278 \mathrm{~d}$ \\
\hline $900 \mathrm{~W}$ & $13 \mathrm{e}$ & $10.64 \mathrm{~b}$ & $0.998 \mathrm{~b}$ & $0.005 \mathrm{~b}$ & $0.1220 \mathrm{a}$ & $1.262 \mathrm{e}$ \\
\hline $\mathrm{LSD}^{\$}$ & 2.0 & 0.37 & 0.002 & 0.0004 & 0.0027 & 0.005 \\
\hline
\end{tabular}

*Means with the same letter in the same column are not significantly different at the 0.05 level.

${ }^{\$}$ LSD = least significance difference.

\section{CONCLUSION}

The drying behavior of okra under microwave drying conditions was studied using different microwave power level $(75,150,300,500,700$ and $900 \mathrm{~W})$. Drying time decreased significantly by application of microwave heating. By increasing the used microwave output powers for drying a 
sample amount of $100 \mathrm{~g}$, the drying time decreased from 19 to 13 min.Drying rates were found increasing with the increase in microwave power. Four empirical drying models were used to fit the drying data. The drying rate constant (k) of Midilli-Kucuk model was found in the range of 0.0813 to $0.122 \mathrm{~min}^{-1}$, the constant ' $\mathrm{n}$ ' was in the range of 1.262 to 1.338 , the constant ' $a$ ' was in the range of 0.997 to 1.008 and the constant ' $b$ ' was in the range of 0.005 to 0.006 . The value of the drying coefficient $(\mathrm{k})$ increased with the increase in microwave power.

\section{REFERENCES}

Adom, K.K., V.P.Dzogbefia and W.O.Ellis.(1997).Combined effect of drying time slice thickness on the solar drying of okra. Journal of the Science and Food Agriculture, 73, 315-320.

AOAC.(1984).Official methods of analysis (14th ed.). Washington, DC: Association of Official Analytical Chemists.

Apar, D., E. Demirhan and G. Dadali.(2009):Rehydration kinetics of microwave-dried okras as affected by drying conditions. Journal of Food Processing and Preservation, 33 (5):618-634.

Brennand, C.P.(1994).Home drying of food. August 1994 (FN-330) http://extension.usu.edu/files/publications/publication/FN-330.pdf

Changrue, V. (2006).Hybrid Osmotic, Microwave-vacuum) Drying of Strawberries and Carrots.Ph.D Thesis, Department of Bioresource Engineering Macdonald Campus of McGill University Ste-Annede-Bellevue, Quebec Canada.

Dadali, G.and B.Özbek.(2009).Kinetic thermal degradation of vitamin C during microwave drying of okra and spinach. International Journal of Food Sciences and Nutrition, 60 (1):21-31.

Dadali, G.,D.K.Apar and B. Ozbek.(2007).Microwave drying kinetics of okra. Drying Technology,25 (5):917-924.

Decareau, R.V.(1985).Microwave in the food processing industry. Academic Press Inc., New York, 234 pp.

Demirhan, E.and B.Özbek.(2010).Microwave-drying characteristics of 
basil. Journal of Food Processing and Preservation, 34 (3):476-494.

Doymaz,I. (2005).Drying characteristics and kinetics of okra. Journal of Food Engineering, 69:275-279.

Grabowski S.and M. Marcotte.(2003). Drying of fruits and vegetables and spices. In: Hand book of postharvest technology: cereals, fruits, vegetables, tea and spices, Chakraverty A., A.S. Mujundar and G.S.V.Raghavan (ed. ) Marcel Dekker, New York: 653-688.

Haghi, A. K. and N. Amanifard.(2008).Analysis of heat and mass transfer during microwave drying of food products. Brazilian Journal of Chemical, Engineering, 25 (3):491- 501.

Henderson, S.M.and S.Pabis. (1961). Grain drying theory I: Temperature effect on drying coefficient.Journal of Agricultural Research Engineering, 6:169- 174.

Inchuen, S., W. Narkrugsa, P. Pornchaloempong, P. Chanasinchana and T. Swing.(2008). Microwave and hot-air drying of Thai red curry paste. Mj. Int. J. Sci. Tech., 1 (Special Issue):38-49.

Kassem,A.S., A. Z. Shokr, A. M. Aboukarima and I. Y. Hamed.(2010).Estimation of moisture ratio of Thompson seedless grapes undergoing microwave drying using artificial neural network and regression models. J. Saudi Soc. For Agric. Sci., 9(1):23-47.

Kassem,A.S., A.Z.Shokr, A. M. Aboukarima and E. Y. Hamed.(2011).Comparison of drying characteristics of Thompson seedless grapes using combined microwave oven and hot air drying.J. Saudi Soc. For Agric. Sci., 10 (1): 33-40.

Kumar, D.and S.Prasad.(2010).Microwave-convective drying characteristics of okra. An ASABE Meeting Presentation, Paper Number: 1008690.

Maskan, M. (2000).Microwave/air and microwave finish drying of banana. Journal of Food Engineering, 44(2):71-78.

Midilli,A., H.Kucuk and Z.Yapar.(2002).A new model for single-layer drying. Drying Technology, 20 (7):1503-1513. 
Mohamed, M.A.,G.R.Gamea and M.H. Keshek. (2010). Drying characteristics of okra by different solar dryers. Misr J. Ag. Eng., 27(1):294-312.

Ong, S. P. and C.L.law.(2009):Mathematical modeling of thin layer drying of salak. Journal of Applied Sciences, 9(17):3048-3054.

Ozbek, B.and G. Dadali. (2007). Thin-layer drying characteristics and modeling of mint leaves undergoing microwave treatment. Journal of Food Engineering, 83:541-549.

Page, C.(1949).Factors influencing the maximum rates of air drying of shelled corn in thin layers.Unpublished M.S. Thesis, Purdue University, Lafayette IN.

Sanga, E., A.S. Mujumdar, G.S.V. Raghavan. (2000). Chapter 10: Principles and applications of microwave drying. In: Drying Technology in Agricultural and Food Sciences, A.S. Mujumdar (ed.).Science Publishers, Enfield, USA: 283-289.

Shah, S.and M.Joshi.(2010).Modeling microwave drying kinetics of sugarcane bagasse. International Journal of Electronics Engineering, 2(1):159-163.

Shivhare, U. S., A. Gupta, A. S. Bawa and P. Gupta.(2000).Drying characteristics and product quality of okra. Drying Technology, 18 (1 \& 2):409 - 419 .

Soysal,Y.(2004).Microwave drying characteristics of parsley. Biosystems Engineering, 89(2), 167-173.

Soysal, Y. (2005). Mathematical modeling and evaluation of microwave drying kinetics of mint (Mentha spicata L. ). Journal of Applied Sciences, 5 (7):1266-1274.

SPSS.(2005).SPSS for Windows Software Version 14.0.

Tontand, S.and N. Therdthai. (2009). Preliminary study of chili drying using microwave assisted vacuum drying technology. As. J. Food Ag-Ind., 2(2):80-86. 
Xanthopoulos,G., N.Oikonomou and G. Lambrinos.(2007).Applicability of a single-layer drying model to predict the drying rate of whole figs. Journal of Food Engineering, 81: 553-559.

الملخص العربي - n

\section{خصائص التجفيف لقرون البامية أثناء عملية التجفيف في فرن ميكرويف منزلي}

\section{عبد الوهاب شلبي قاسم'، عبد الواحد محمد أبوكريمةّ و حمزة عبد العزيز الميرغنيّ}

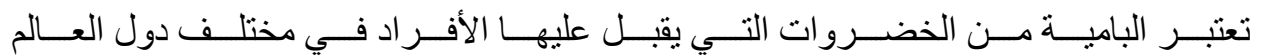

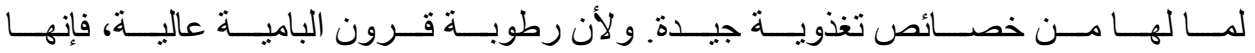

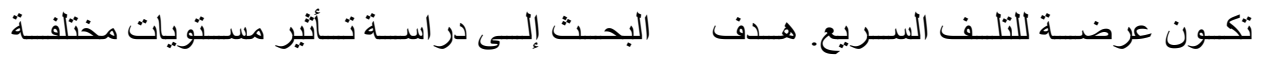

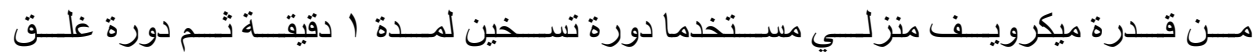

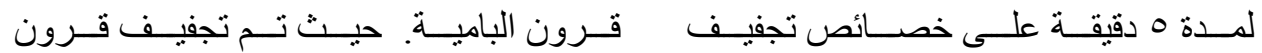

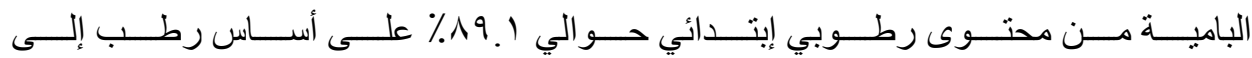

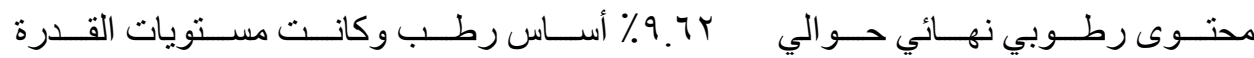

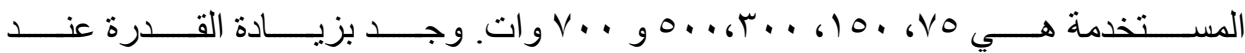

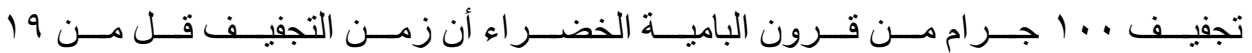

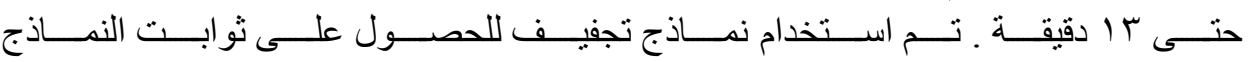

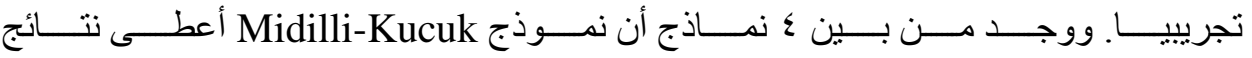

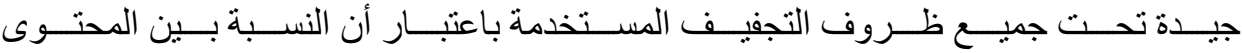

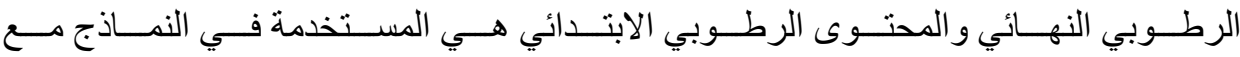

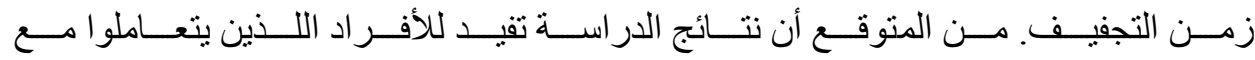
نظم التجفيف بالميكرويف مستقبلا.

1.أستاذ، قسم الهندسة الزراعية، كلية الزراعة، جامعة الإسكندرية، ج.م.ع.

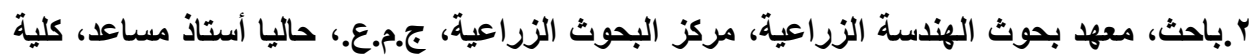
المجتمع، جامعة شقراء، المملكة العربية السعودية.

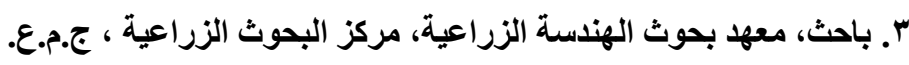

